\title{
PUSAT LITERASI KOTA PONTIANAK
}

\author{
Yoris Mangenda ${ }^{1}$, Emilya Kalsum ${ }^{2}$, Bontor Jumaylinda Br. Gultom ${ }^{3}$ \\ ${ }^{1}$ Mahasiswa, Program Studi Arsitektur, Fakultas Teknik, Universitas Tanjungpura. \\ yorismangenda@gmail.com \\ ${ }^{2}$ Program Studi Arsitektur, Fakultas Teknik, Universitas Tanjungpura \\ ${ }^{3}$ Program Studi Arsitektur, Fakultas Teknik, Universitas Tanjungpura
}

Naskah diajukan pada: 18 September 2020

Naskah revisi akhir diterima pada: 21 September 2020

\begin{abstract}
Abstrak
Central Connecticut State Univesity pada tahun 2016 menyatakan, Indonesia menduduki peringkat ke-60 dari 61 negara soal literasi. Menurut UNESCO literasi adalah kemampuan untuk mengidentifikasi, mengerti, menginterpretasi, berkomunikasi, dengan konteks yang bervariasi. Indeks Alibaca Nasional mengatakan, sebagian besar provinsi di Indonesia memiliki indeks literasi yang rendah, termasuk provinsi Kalimantan Barat yang berada pada peringkat ke-3 dari 34 provinsi. Walaupun demikian, di Kota Pontianak dalam 5 tahun terakhir justru gencar diadakannya berbagai kegiatan berbasis literarsi seperti pameran, book fair, diskusi, serta tercatat lebih dari 20 komunitas literasi pada tahun 2019. Seluruh kegiatan literasi tersebut diorganisir secara mandiri dan tidak terdapat ruang khusus. Oleh karena itu, mempertimbangkan kebutuhan dan permasalahan literasi, maka lokasi yang potensial dijadikan area perancangan berada di Jl. Jenderal Ahmad Yani, Kota Pontianak. Namun, terdapat permasalahan di mana belum adanya standarisasi yang dapat dijadikan sebagai acuan untuk mendesain sebuah Pusat Literasi. Oleh karena itu, metode perancangan yang digunakan adalah metode Design Thinking, yang menurut Kambel (2009), suatu pendekatan kreatif dengan mengumpulkan informasi dan peluang yang ada untuk di sintesis menjadi inovasi dan ide karya. Melalui metode ini ditemukan fasilitas seperti ruang pameran, kelas, baca dan koleksi, serta tatanan ruang dan bentuk yang potensial untuk mewadahi kegiatan literasi di Kota Pontianak.
\end{abstract}

Kata-kata Kunci: Literasi, Pusat Literasi, Design Thinking

\begin{abstract}
Central Connecticut State University stated in 2016, Indonesia was ranked 60th out of 61 countries regarding literacy. According to UNESCO literacy is the ability to identify, understand, interpret, communicate, in various contexts. The National Alibaca Index said that most provinces in Indonesia have a low literacy index, including West Kalimantan, which is ranked 3rd out of 34 provinces. However, in Pontianak City, in the last 5 years, various literacy-based activities such as exhibitions, book fairs, discussions have been intensively held, as well as recorded more than 20 literacy communities in 2019. All literacy activities are organized independently and have no special space. Therefore, considering literacy needs and problems, the potential location for the design area is Jl. General Ahmad Yani, Pontianak City. However, there are problems where there is no standardization that can be used as a reference for designing a Literacy Center. Therefore, the design method used is the Design Thinking method, which, according to Kambel (2009), is a creative approach by gathering information and opportunities available to be synthesized into innovation and work ideas. Through this method, facilities such as exhibition rooms, classrooms, reading and collection, as well as spatial arrangements and forms are found to accommodate literacy activities in Pontianak.
\end{abstract}

Keywords: Literacy, Literacy Center, Design Thinking

\section{Pendahuluan}

UNESCO pada tahun 2016 menyebutkan jika Indonesia adalah Negara urutan kedua dari bawah soal literasi dunia. Sedangkan dalam riset berbeda bertajuk World's Most Literate Nations Ranked yang dilakukan oleh Central Connecticut State Univesity pada Maret 2016, Indonesia dinyatakan menduduki peringkat ke-60 dari 61 negara soal minat membaca. Tidak hanya persoalan 
makro, dalam dalam buku "Indeks Aktivitas Literasi Membaca 34 Provinsi” yang dikeluarkan oleh "Pusat Penelitian Kebijakan Pendidikan dan Kebudayaan", menyatakan jika indeks literasi sebagian besar provinsi masuk ke dalam kategori rendah. Tiga puluh empat provinsi di Indonesia, 9 provinsi (26\%) di antaranya masuk ke dalam kategori aktivitas literasi sedang (angka indeks antara 40,01 60,00); 24 provinsi (71\%) masuk kategori rendah (20,01 - 40,00); dan 1 provinsi (3\%) masuk kategori sangat rendah $(0-20,00)$, yang atinya sebagian besar provinsi berada pada level aktivitas literasi rendah dan tidak satu pun provinsi termasuk ke dalam level aktivitas literasi tinggi dan sangat tinggi.

Kota Pontianak yang merupakan Ibu Kota provinsi Kalimantan Barat, dari segi fasilitas dan pengelolaan literasi dapat dikatakan masih dalam taraf di bawah rata-rata. Hal tersebut ditujukan dalam "RKPD Kota Pontianak tahun 2014", yang mengatakan SDM dalam pengelolaan dan pengorganisiran aktivitas literasi di Pontianak masih sangat minim, serta gedung-gedung yang dikatakan tidak memiliki posisi yang strategis dan fasilitas yang jauh dibawa standar yang berlaku. Selain daripada itu, berkenaan dengan tempat atau lokasi dalam penyenggaraan kegiatan yang berbasis literasi juga tidak ada, adapun ruang-ruang yang di gunakan selama ini, dikatakan hanya bersifat seadanya. Namun walaupun demikian, sebagaimana yang di kutip oleh Tribun Pontianak pada tahun 2017, mengatakan jika, perkembangan literasi di Kota Pontianak dalam 5 tahun terakhir berkembang begitu pesat di tengah minimnya fasilitas literasi yang ada di Kota Pontianak.

Aktivitas dan kegitan literasi pada dasarnya memiliki kompleksitas yang berbeda dari hanya sekedar sebuah fasilitas baca dan tulis. Terdapat berbagai variabel yang menjadi tolak ukur di dalam literasi seperti, basic literacy, computer literacy, media literacy, distance Learning, cultural literacy, information literacy, sampai kepada visual literacy. Selain daripada itu terdapat pula kegiatankegiatan literasi yang pada dasarnya belum memiliki wadah di Kota Pontianak seperti, bazar buku, pameran, sampai kepada komunitas-komunitas literasi. Oleh karena itu, dengan rendahnya indeks literasi di Indonesia maupun Kalimantan Barat serta minimnya fasilitas literasi di Kota Pontianak di tengah gencarnya komunitas-komunitas literasi yang sampai saat ini masih bergerak secara mandiri, maka permasalahan ini layak untuk diselesaikan.

\section{Kajian Pustaka}

Literasi menurut UNESCO dalam Assessment, C. (2013) tentang What is Literacy? merupakan kemampuan untuk mengidentifikasi, untuk dapat mengerti, menginterpretasi, menciptakan, berkomunikasi dan menghitung, menggunakan alat-alat cetak dan tulisan yang telah tertera dengan konteks yang bervariasi. Literasi melibatkan sebuah pembelajaran berkelanjutan dalam memungkinkan individu untuk mencapai tujuan mereka, untuk mengembangkan pengetahuan dan potensi, dan untuk berpartisipasi penuh di dalam komunitas dan kehidupan sosial yang lebih luas. Selain daripada itu Menurut Clay (2001), literasi akan terdiri dari macam-macam kategori yaitu literasi dini, literasi dasar, literasi perpustakan, literasi media, literasi teknologi, literasi visual.

Menurut Kren (2000), terdapat tujuh prinsip yang dilibatkan dalam pendidikan literasi, yaitu; interpretasi, kolaborasi, konvensi, pengetahuan kultural, pemecahan masalah, refleksi diri, sampai kepada penggunaan bahasa. Implementasi prinsip tersebut menurut UNESCO yang dikutip oleh (Nasution, 2013), yaitu terdapat enam kategori model di dalam pengembangan kemampuan literasi pada abad 21 yang di antaranya; basic Literacy, computer literacy, media literacy, distance learning, cultural literacy, serta information literacy.

Keberhasilan sebuah program atau model literasi menurut Miller dan McKenna (2016), terbagi menjadi 4 faktor yang akan mempengaruhinya yaitu proficiency atau kecakapan merupakan syarat awal agar seseorang dapat mengakses sumber-sumber literasi, access merupakan sumber daya pendukung di mana masyarakat dapat memanfaatkan sumber-sumber literasi, alternatives ialah beragam pilihan perangkat teknologi informasi dan hiburan, culture meliputi gagasan, nilai, norma, 
dan makna yang dibentuk oleh keluarga, komunitas, dan lingkungan yang lebih luas yang turut memengaruhi perilaku literasi.

\section{Metode}

Metode perancangan yang digunakan untuk mengorganisir kompleksitas dan permasalahan literasi yaitu metode Design Thinking, yang menurut Kambel (2009), suatu pendekatan kreatif dengan mengumpulkan informasi dan peluang yang ada untuk di sintesis menjadi inovasi dan ide karya. Sedangkan menurut Brown (2009), merumuskan design thinking sebagai sebuah metode untuk menciptakan nilai bagi calon pengguna dan peluang pasar secara keseluruhan bukan hanya berdasarkan penampilan dan fungsi saja. Adapun elemen-elemen di dalam design thinking menurut Ali (2017) di antaranya; People centered, Highly creative, Hands on, serta Iterative, serta memiliki beberapa tahapan yang menurut De Yong (2017), di mulai dari Empathize, Define, Ideate, Prototype, serta Test. Adapun diagram metode ataupun tahapan Pusat Literasi Kota Pontianak dapat dilihat pada Gambar 1 berikut.

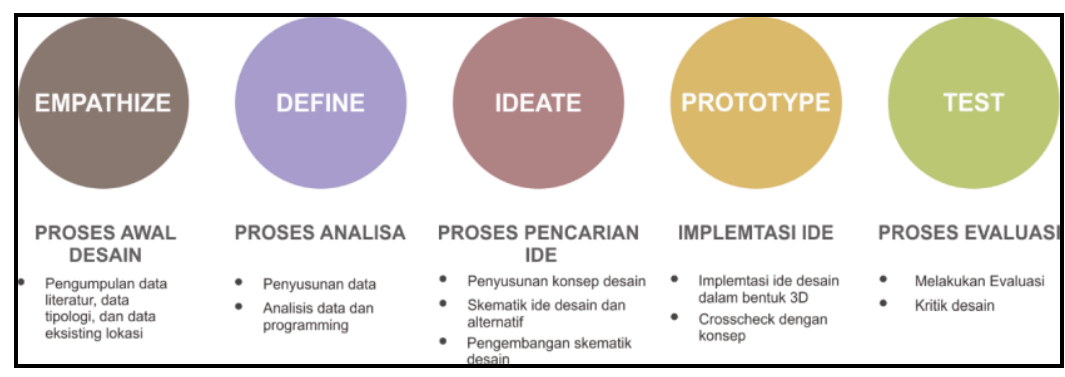

Gambar 1. Diagram Tahapan Metode Design Thinking Sumber : Penulis, 2020

\section{Hasil dan Pembahasan}

\section{Lokasi Perancangan}

Lokasi Pusat Literasi Kota Pontianak berlokasikan di zonasi strategis Kota Pontianak dalam Rencana Pola Ruang Kota Pontianak 2013-2033. Selain itu, berdekatan dengan lokasi perancangan (Taman Digulis, Auditorium UNTAN, serta Taman Catur) juga kerap di jadikan ruang bagi berbagai komunitas literasi untuk melangsungkan berbagai kegiatan berbasis literasi seperti diskusi, bagai buku, dan lain-lain. Sehingga kali dari segi aksesibilitas dan efektivitas lokasi dalam konteks literasi dinilai potensial.

Lokasi spesifik perancangan berada di antara Jl. Jenderal Ahmad Yani (jalan arteri primer) dengan lebar 18 meter, Jl. Tanjung Harapan yang memiliki lebar 6 meter serta Jl. Tanjung Sari yang memiliki lebar 3 meter, Kota Pontianak, Kalimantan Barat. Area ini di dalam Rencana Tata Ruang Kota Pontianak 2013-2033 di peruntukan untuk zonasi perdagangan dan jasa. Tapa perancangan memiliki luas $11.219 \mathrm{~m}^{2}$ atau $\pm 1.1 \mathrm{Ha}$, dengan ketentuan Koefisien Dasar Bangunan (KDB) sebesar $60 \%$ setara dengan $6.731 \mathrm{~m}^{2}$, Koefisien Dasar Hijau (KDH) sebar $40 \%$ setara dengan $4.488 \mathrm{~m}^{2}$, serta Koefisien Lantai Bangunan (KLB) sebesar 4,8 atau 8 lantai. Sedangkan untuk ketentuan Garis Sempadan Bangunan (GSB) pada bagian yang bersinggungan dengan Jl. Jenderal Ahmad Yani sebesar 17.5 m, Jl. Tanjung Harapan 10 m, dan Jl. Tanjung Sari 3 m. 


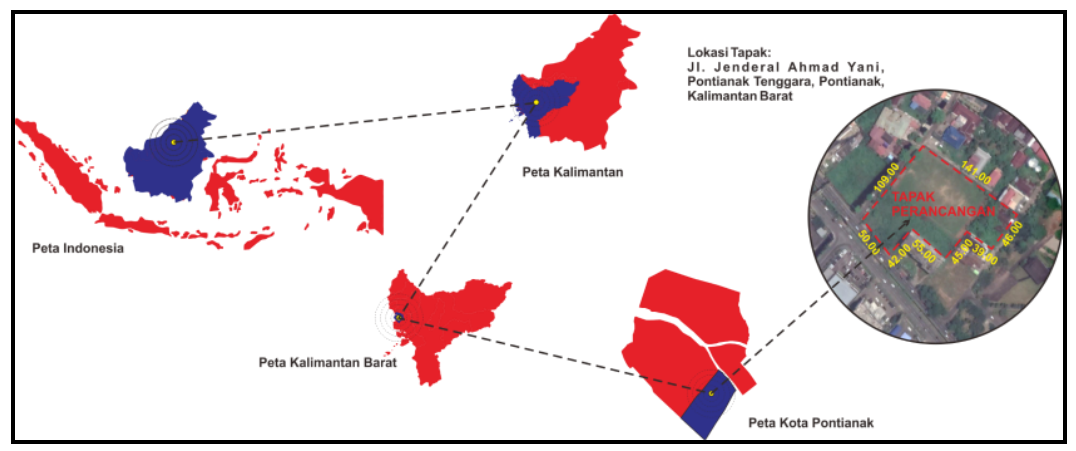

Gambar 2. Lokasi Perancangan Pusat Literasi Kota Pontianak Sumber: Penulis, 2020

\section{Fungsi}

Fungsi yang dirancang merupakan hasil analisis dari berbagai tinjauan dan kegiatan literasi yang ada di Kota Pontianak. Adapun fungsi utama dari bangunan ini terbagi menjadi 3 kategori yaitu fungsi edukasi, fungsi informasi, serta fungsi komersil. Fungsi informasi, merupakan fungsi yang memberi, menyebarkan, serta memfasilitasi berbagai kegiatan penggalian dan pencarian informasi yang dalam hal ini seperti menyediakan berbagai koleksi buku dan literatur, berperan sebagai media, mengadakan berbagai event serta workshop, informasi cultural, serta kegiatan-kegiatan lain yang dalam lingkup penyaluran informasi. Fungsi edukasi adalah fungsi yang memberikan, menyediakan dan memfasilitasi kegiatan edukasi yang di butuhkan di Kota Pontianak seperti, bimbingan belajar, pelatihan, berbagai event literasi seperti pameran, bedah buku serta kegiatan lain yang berkaitan dengan edukasi. Fungsi komersial, merupakan fungsi yang berperan sebagai penunjang seluruh kegiatan yang ada di dalam bangunan dan sekaligus dapat menjadi sumber pemasukan bangunan. Untuk lebih jelas mengenai fungsi dan landasannya dapat dilihat pada Gambar 3 berikut ini.

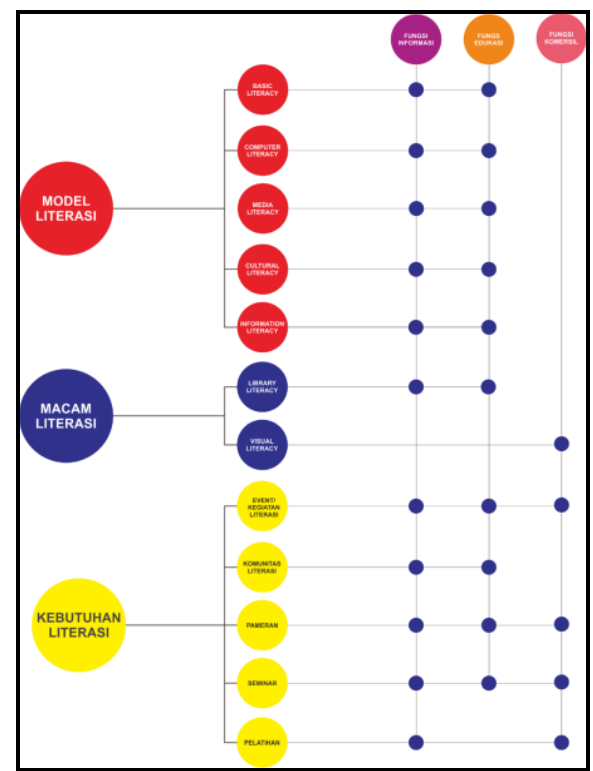

Gambar 3. Diagram Fungsi Pusat Literasi Kota Pontianak

Sumber: Penulis, 2020

\section{Ide Perancangan}

Konsep ide di dalam perancangan Pusat Literasi Kota Pontianak adalah merancang sebuah fasilitas literasi kompleks dalam rangka menunjang, memfasilitasi, serta di harapkan mampu menarik 
minat masyarakat dalam budaya literasi dan pada akhirnya berkontribusi dalam meningkatkan indeks literasi di Kota Pontianak. Adapun diagram konseptual dari konsep ide perancangan dapat dilihat pada Gambar 4 berikut ini.

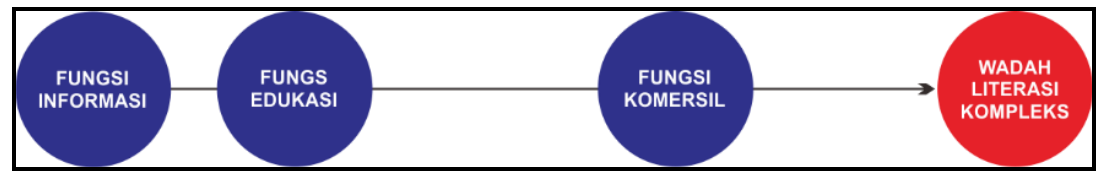

Gambar 3: Diagram Fungsi Pusat Literasi Kota Pontianak Sumber: Penulis, 2020

\section{Tema Perancangan}

Tema perancangan mengacu pada rumusan ide serta beberapa penyelesaian permasalahan utama perancangan serta pengembangan dari metode perancangan. Mengingat belum adanya fasilitas kompleks yang mewadahi aktivitas dan kegiatan literasi serta belum adanya standar yang baku di dalam perancangan Pusat Literasi dan fasilitas khusus literasi di Kota Pontianak. Oleh karena itu, tema yang kemudian di anggap potensial dan menjadi konsep dalam perancangan adalah Oasis of Literacy. Tema ini yang merupakan bentuk penekanan dan harapan terhadap Pusat Literasi yang akan menjadi salah satu wadah literasi terbesar di Kota Pontianak di tengah rendahnya indeks literasi masyarakat. Serta dapat menjadi sebuah sumber yang dapat menarik dan menjadi tempat tujuan bagi setiap individu dan kelompok yang butuh akan literasi.

\section{Konsep Program Ruang}

Konsep program ruang di dalam perancangan Pusat Literasi Kota Pontianak terbagi menjadi 2 klasifikasi yaitu program ruang makro dan mikro. Program ruang makro pada umumnya merupakan ruang-ruang utama yang menjadi landasan di dalam perancangan Pusat Literasi ini. Ruang-ruang tersebut mencakup ruang-ruang seperti ruang pameran, teater, workshop/seminar, kelas, hingga ruang-ruang gallery. Sedangkan program ruang mikro merupakan ruang-ruang yang di hasilkan melalui penjabaran aktivitas dari pelaku-pelaku yang terlibat, maka program ruang makro akan berisi ruang-ruang seperti ruang-ruang pengelola, ruang-ruang umum seperti lobby, sampai kepada ruangruang servis bangunan. Untuk lebih jelas mengenai inventarisasi fasilitas dan ruang yang terdapat dalam perancangan Pusat Literasi Kota Pontianak dapat dilihat pada Tabel 1 berikut.

Tabel 1. Inventarisasi Ruang Pusat Literasi Kota Pontianak

\begin{tabular}{|c|c|c|c|}
\hline No & Kategori Ruang & Nama Ruang & \\
\hline \multirow[t]{9}{*}{1} & \multirow{9}{*}{$\begin{array}{l}\text { Kelompok Ruang } \\
\text { Pengelolaan }\end{array}$} & - Ruang Kepala Pusat Literasi & - Ruang CCTV \\
\hline & & - Sekretaris & - Ruang Staf Kebersihan \\
\hline & & - Unit Layanan Membaca & - Ruang Janitor \\
\hline & & - Ruang Area Loading & - Pantry \\
\hline & & - Unit Komunitas & - Ruang Staf MEE \\
\hline & & - Ruang Instruktur & - Ruang Panel \\
\hline & & - Ruang Unit Media \& Informasi & - Ruang Genset \\
\hline & & - Ruang Arsip Dokumen & - Ruang Server \\
\hline & & - Ruang Security & \\
\hline \multirow[t]{3}{*}{2} & \multirow[t]{3}{*}{$\begin{array}{l}\text { Kelompok Ruang } \\
\text { Pengunjung }\end{array}$} & - Ruang Komunitas & $\begin{array}{l}\text { - Ruang Baca \& Belajar } \\
\text { Anak }\end{array}$ \\
\hline & & - Ruang Diskusi & $\begin{array}{l}\text { - Ruang Belajar \& Baca } \\
\text { Umum }\end{array}$ \\
\hline & & - Ruang Workshop/Seminar & - Ruang Arsip Literasi \\
\hline
\end{tabular}




\begin{tabular}{|c|c|c|c|}
\hline & & - Ruang Serbaguna & - Ruang Gallery Visual \\
\hline & & - Perpustakaan Umum & - Studio Tulis \\
\hline & & - Perpustakaan Anak & - Ruang Pameran \\
\hline & & - Children Digital Library & - Ruang Teater \\
\hline & & - Library Digital & - Ruang Kelas Anak \\
\hline & & - Ruang Multimedia & - Ruang Kelas Umum \\
\hline 3 & Kelompok ruang & - Lobby Utama & - ATM Center \\
\hline & Penunjang & - Lobby Pengelola & - Toilet Pria \\
\hline & & - Ruang Tunggu & - Toilet Wanita \\
\hline & & - Loker & - Toilet Difabel \\
\hline & & - Mushola & - Parkir Pengelola \\
\hline & & - Kafetaria & - Parkir Pengunjung \\
\hline & & - Toko Buku & \\
\hline
\end{tabular}

Sumber: Penulis, 2020

\section{Konsep Tapak}

Konsep tapak di dalam perancangan Pusat Literasi Kota Pontianak akan terbagi menjadi 5 kategori yaitu zoning, orientasi, sirkulasi, perletakan serta vegetasi. Konsep zoning pada dasarnya merupakan hasil komparasi dari seluruh elemen analisis tapak seperti orientasi matahari, arah angin, iklim, tautan lingkungan, sirkulasi, serta view yang kemudian menghasilkan beberapa zonasi yang terdiri dari publik, semi publik, privat, semi privat, serta servis. Zonasi publik dan privat akan menghindari arah barat (sinar matahari yang membawa panas), oleh karena itu bagian barat tapak akan difokuskan sebagai peruntukan area servis. Adapun penempatan setiap kategori zonasi tersebut terhadap tapak dapat dilihat pada Gambar 4 berikut ini.

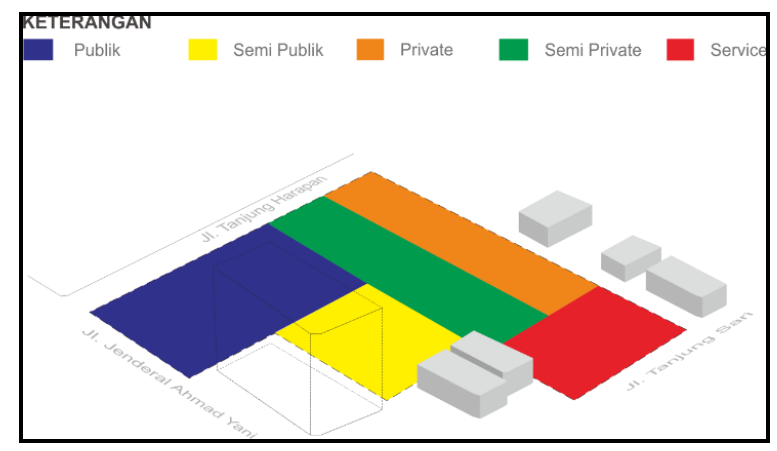

Gambar 4. Konsep Zoning

Sumber: Penulis, 2020

Konsep orientasi arah orientasi pada Pusat Literasi Kota Pontianak akan di prioritaskan ke arah Barat atau sekitaran Jl. Jenderal Ahmad Yani. Hal ini dikarenakan dari segi klasifikasi jalan maupun tautan lingkungan, arah barat atau Jl. Jenderal Ahmad Yani ini memiliki potensi yang besar, terutama dalam hal aksesibilitas serta lebih mudah untuk di akses dari segi view ketimbang bagian lainnya. Untuk ilustrasi arah orientasi dapat dilihat pada Gambar 5 berikut. 


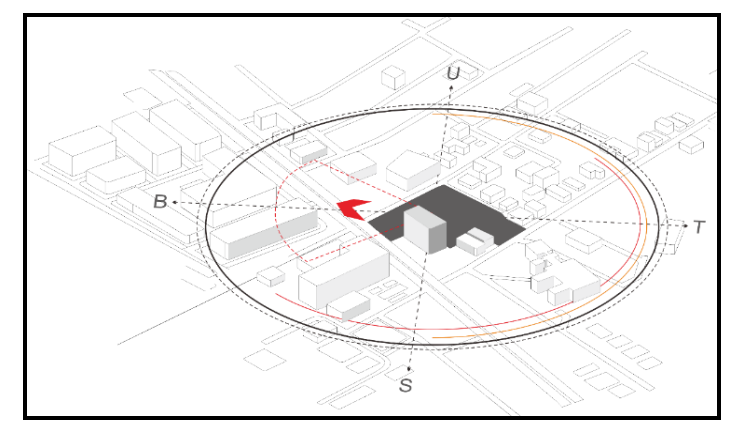

Gambar 5. Konsep Orientasi

Sumber: Penulis, 2020

Konsep sirkulasi pada perancangan Pusat Literasi Kota Pontianak yaitu membagi sirkulasi di dalam tapak menjadi 3 jalur. Jalur sirkulasi yang bersinggungan dengan Jl. Jenderal Ahmad Yani diperuntukkan sebagai jalur sirkulasi masuk utama pada bangunan. Hanya terdapat 1 jalur pada area ini, yaitu sirkulasi masuk dan tidak ada sirkulasi keluar yang akan mengarah pada Jl. Jenderal Ahmad Yani. Selanjutnya yaitu sirkulasi masuk sekunder dan sirkulasi keluar di tempatkan pada area yang bersinggungan langsung dengan Jl. Tanjung Harapan serta Tanjung Sari. Untuk lebih jelas mengenai ilustrasi ketiga jalur sirkulasi pada tapak perancangan dapat dilihat pada Gambar 6 berikut.

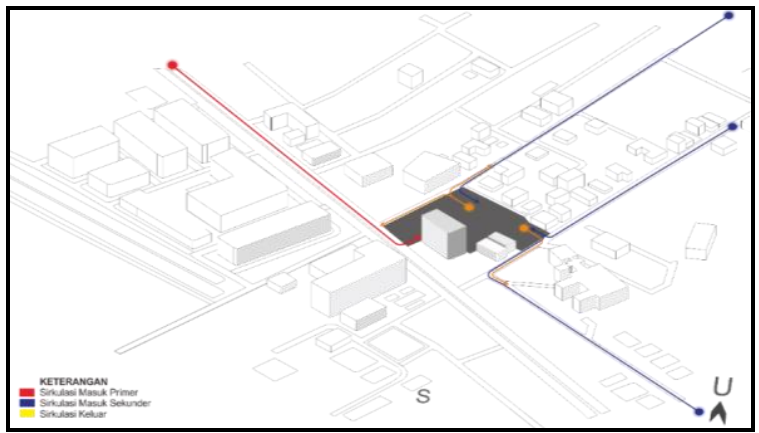

Gambar 6. Konsep Sirkulasi

Sumber : Penulis, 2020

Konsep perletakan masa bangunan yang akan erat kaitannya dengan peraturan yang berlaku pada tapak perancangan. Luas total masa bangunan tidak lebih dari $6.731 \mathrm{~m}^{2}$. Perletakan masa bangunan pada bagian yang bersinggungan dengan Jl. Jenderal Ahmad Yani akan menyesuai Ian GSB yaitu $17.5 \mathrm{~m}$, pada Jl. Tanjung Harapan $10 \mathrm{~m}$, sedangkan pada Jl. Tanjung Harapan $3 \mathrm{~m}$. Sedangkan untuk perletakan masa bangunan yang bersinggungan dengan ruko pada Jl. Jenderal Ahmad Yani, akan didempetkan dengan dinding ruko tersebut. Untuk lebih jelas mengenai perletakan masa bangunan dapat dilihat pada Gambar 7 berikut.

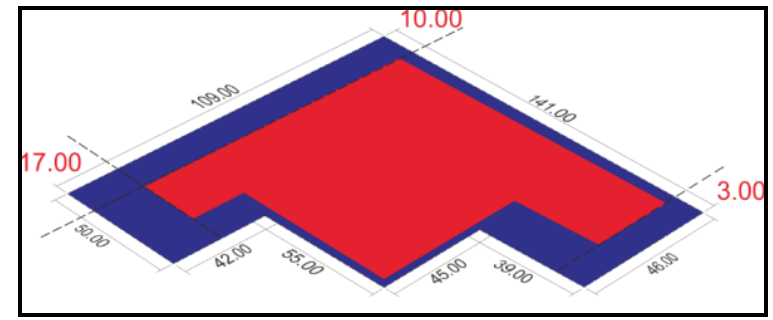

Gambar 7. Konsep Perletakan

Sumber: Penulis, 2020 
Konsep vegetasi pada perancangan Pusat Literasi Kota Pontianak adalah memadukan serta menempatkan berbagai jenis vegetasi sesuai fungsi dan kebutuhannya. Terdapat 3 jenis kelompok vegetasi yang akan di gunakan yang di antaranya jenis vegetasi pucuk merah yang memiliki fungsi yang bersifat menghalang yaitu untung menciptakan view serta menghalang view-view yang tidak potensial di beberapa arah, vegetasi jenis ketapang kencana, yaitu vegetasi yang memiliki fungsi sebagai estetika, serta jenis vegetasi beringinan yang memiliki fungsi peneduh atau menghalau kebisingan yang dapat mengganggu aktivitas di dalam tapak.

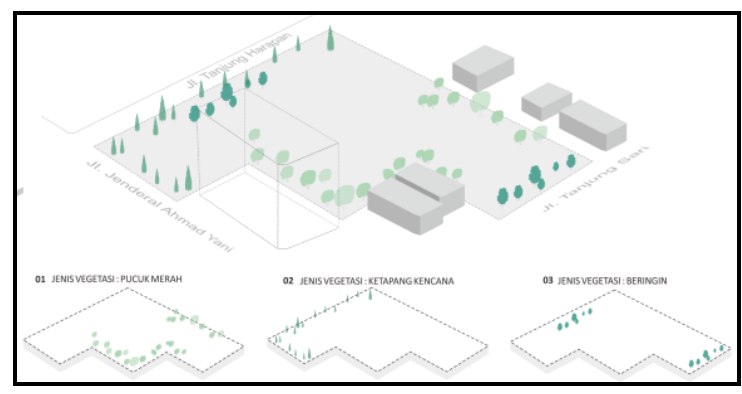

Gambar 8. Konsep Vegetasi

Sumber: Penulis, 2020

\section{Konsep Bentuk}

Konsep bentuk pada perancangan memiliki 2 landasan konseptual, yaitu kontekstual dan filosofi. Landasan kontekstual merupakan analisis-analisis yang berkaitan dengan kondisi existing yang ada pada tapak. Sedangkan landasan filosofi akan lebih berkaitan dengan aspek-aspek mendasar yang menjadi esensi dari sebuah aktivitas literasi. Adapun proses dan keterangan dari setiap transformasi tersebut dapat dilihat pada Gambar 9 berikut.

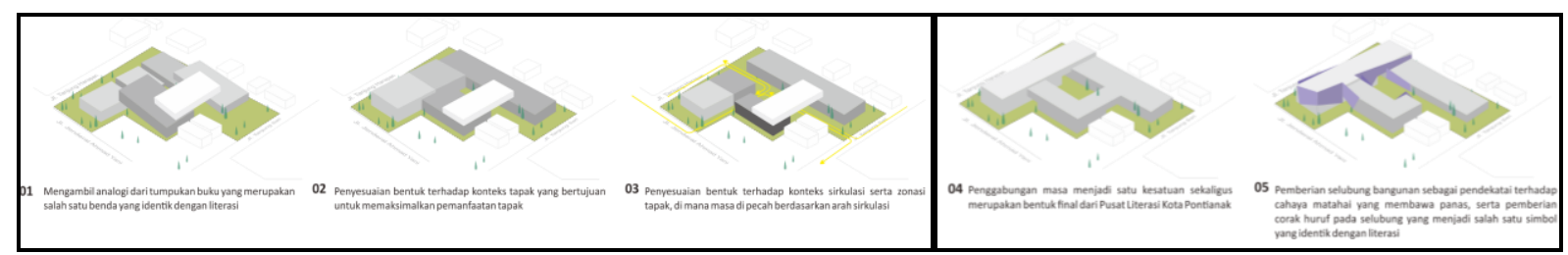

Gambar 9: Konsep Bentuk

Sumber: Penulis, 2020

\section{Konsep Struktur}

Sistem struktur yang di gunakan di dalam perancangan Pusat Literasi Kota Pontianak adalah sistem struktur beton bertulang. Adapun jenis fondasi yang di gunakan yaitu akan menggunakan fondasi tiang pancang, hal ini mengingat kondisi tanah pada tapak yang memiliki muka air yang tinggi serta jenis tanah gambut. Sedangkan untuk modul struktur akan terbagi menjadi 2 kategori yaitu $8 \times 8$ dan $5 \times 5$. Kedua klasifikasi modul tersebut di dapatkan melalui perhitungan yang di lakukan berkenaan dengan KPK (Kelipatan Persekutuan terkecil) dari dimensi-dimensi ruang yang ada. Di dalam implementasi sistem struktur terhadap konsep bentuk, akan di lakukan beberapa dilatasi struktur di beberapa sudut bentuk. Hal ini di lakukan untuk menyikapi ketinggian bangunan yang berbeda yang kemudian berpengaruh kepada beban yang akan di pikul oleh masing-masing sistem struktur. Oleh karena itu terdapat 5 titik dilatasi yang terdapat di dalam mekanisme struktur yang ada. Sedangkan untuk konstruksi atap, akan menggunakan 2 jenis konstruksi atap yaitu beton bertulang dengan mekanisme atap datar serta atap miring. Untuk lebih jelas mengenai mekanisme struktur yang telah dipaparkan dapat dilihat pada Gambar 10 berikut ini. 


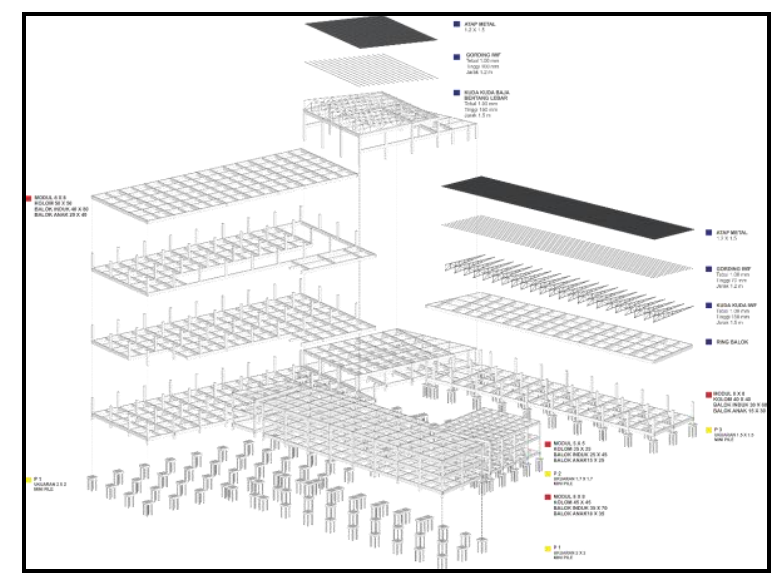

Gambar 10. Konsep Struktur

Sumber: Penulis, 2020

\section{Konsep Utilitas}

Konsep utilitas terdiri dari 5 variabel yang di dalamnya terdapat mekanisme jaringan air, jaringan listrik, tata udara, keamanan bangunan serta persampahan. Berkenaan dengan sistem jaringan air akan terbagi menjadi sistem jangan air bersih yang akan memanfaatkan sistem downfeed, sistem jaringan limbah padat, serta limbah cair. Jaringan listrik akan menggunakan jaringan listrik dari PLN serta disediakan pula sebuah genset sebagai antisipasi jika terjadi gangguan. Untuk sistem tata udara pada bangunan akan menggunakan sistem penghawaan buatan berupa jenis $A C$ $V R V$ yang penempatan outdoor $A C$ nya berada pada bagian atas bangunan. Sedangkan untuk sistem keamanan bangunan, pada dasarnya akan berpedoman pada standar-standar yang belaku dalam lingkup fungsi bangunan ini, seperti halnya penyediaan sprinkler dengan jarak pemasangan 4,6 m, penyediaan hydrant box dan lapangan, titik kumpul, tangga darurat, sampai kepada konstruksi tahan api. Variabel terakhir yaitu persampahan, akan disediakan sebuah TPA pada area servis di luar bangunan. Untuk lebih jelas mengenai mekanisme utilitas tersebut dapat dilihat pada Gambar 11 berikut ini.

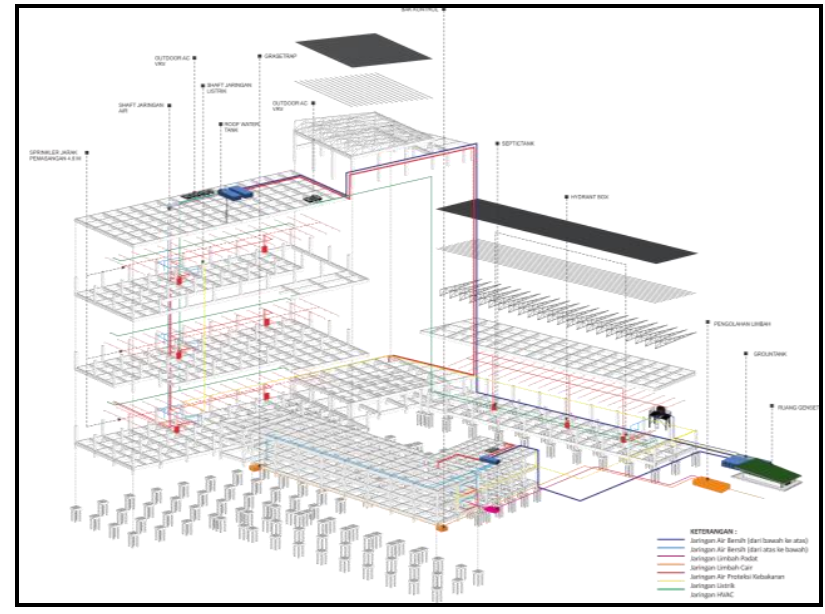

Gambar 11: Konsep Utilitas Bangunan

Sumber: Penulis, 2020 


\section{Konsep Fisika Bangunan}

Konsep fisika bangunan terbagi menjadi konsep pencahayaan, konsep termal serta akustika. Konsep pencahayaan di dalam perancangan Pusat Literasi Kota Pontianak lebih kepada pemanfaatan secondary skin sebagai solusi untuk menetralisir silau yang menerpa sisi barat dan timur masa bangunan. Selain itu, mengingat aktivitas di dalam ruangan yang cenderung membutuhkan pencahayaan yang optimal, maka solusi permasalahan tersebut adalah dengan pengadaan skylight yang langsung terhubung dengan void bangunan sehingga cahaya yang masuk tidak memiliki intensitas silau yang tinggi. Sedangkan untuk konsep termal pada bangunan, akan terbagi menjadi 2 konsep yang berbeda yaitu konsep penghawaan alam dan penghawaan buatan. Berkenaan dengan penghawaan alami akan memanfaatkan ventilasi silang untuk membuat sirkulasi di dalam ruang terus berjalan, serta membuat void-void agar persebaran udara dapat merata. Sedangkan untuk konsep penghawaan buatan akan menggunakan jaringan sistem AC VRV untuk memenuhi standar kenyamanan termal pada ruang-ruang tertentu. Variabel konsep fisika bangunan yang terakhir yaitu akustika, akan cenderung fokus pada pemanfaatan material yang dapat meneralisir kebisingan seperti kayu, material berpori serta karpet. Selain itu, bentukan dan material plafond pada ruang-ruang tertentu juga akan di tangani secara intensif, hal ini tentunya bertujuan untuk menjaga kualitas akustika setiap ruang tetap terjaga sesuai dengan bungsu utama bangunan yang pada dasarnya membutuhkan hal tersebut. Untuk lebih jelas mengenai ilustrasi konsep fisika bangunan dapat dilihat pada Gambar 12 berikut.

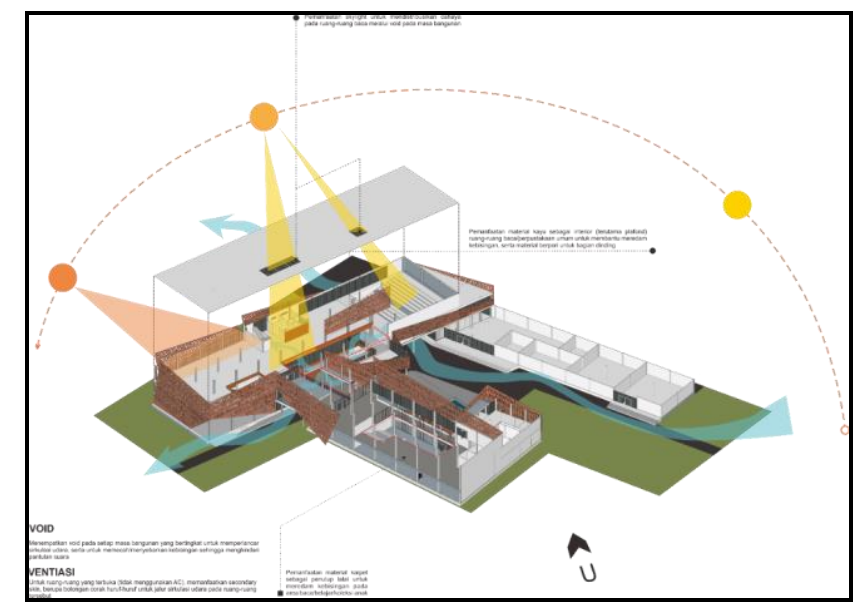

Gambar 12. Konsep Utilitas Bangunan

Sumber: Penulis, 2020

\section{Siteplan}

Siteplan Pusat Literasi Kota Pontianak terbagi menjadi 3 jalur sirkulasi yang akan dijadikan jalur keluar masuk tapak yaitu area yang bersinggungan langsung dengan jalan-jalan utama yang berada di sekitar tapak. Khusus jalur sirkulasi yang bersinggungan dengan Jl. Jenderal Ahmad Yani, hanya akan disediakan jalur masuk dan tidak terdapat jalur keluar pada area ini. Selain dari pada itu, pada Jl. Jenderal Ahmad Yani juga akan disediakan jalur lambat dengan lebar kurang lebih 2.5 meter. Parkir di dalam siteplan akan terbagi menjadi 3 kalsifikasi, yaitu parkir untuk mobil berjumlah 44 untuk umum dan 6 pengelola, parkir motor berjumlah 232 untuk umum dan 12 pengelola, serta 3 parkir bus. Zonasi pada area siteplan juga terpadat sebuah area servis yang memang khusus di peruntukan untuk mengorganisir seluruh aktivitas servis bangunan, seperti halnya untuk peruntukan ruang genset, ground tank, tempat sampah (TPA), dan sebagainya. Area service tersebut berada pada bagian Timur tapak tepatnya bersinggungan langsung dengan Jl. Tanjung Sari. 
Untuk lebih jelas mengenai siteplan Pusat Literasi Kota Pontianak dapat dilihat pada Gambar 13 berikut ini.

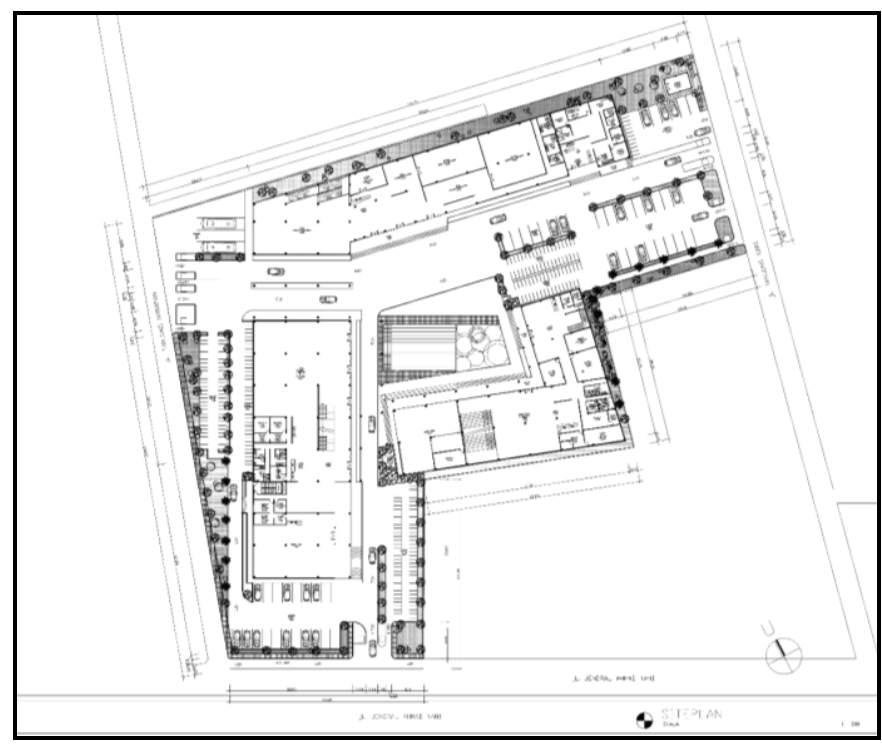

Gambar 13. Siteplan

Sumber: Penulis, 2020

\section{Denah}

Tata ruang dalam pada Pusat Literasi terbagi menjadi 3 tingkatan. Denah lantai dasar akan memiliki beberapa fungsi dan kelompok ruang di dalamnya. Secara garis besar adapun kelompok ruang tersebut yaitu kelompok ruang pengelola, ruang seminar/workshop, gallery, lobby utama, bookstore, kafetaria, ruang baca dan koleksi anak, serta ruang kelas. Selain daripada itu, terdapat beberapa titik kelompok ruang servis pada lantai dasar ini yang akan diteruskan secara vertikal ke lantai-lantai berikutnya. Penempatan zonasi servis ini tentunya sudah sesuai dengan kebutuhan fungsi-fungsi yang ada. Selain itu, penerusan vertikal zonasi servis ini pada umumnya bertujuan untuk kemudahan konstruksi bangunan. Untuk denah lantai dasar bangunan dapat dilihat pada Gambar 14 berikut ini.

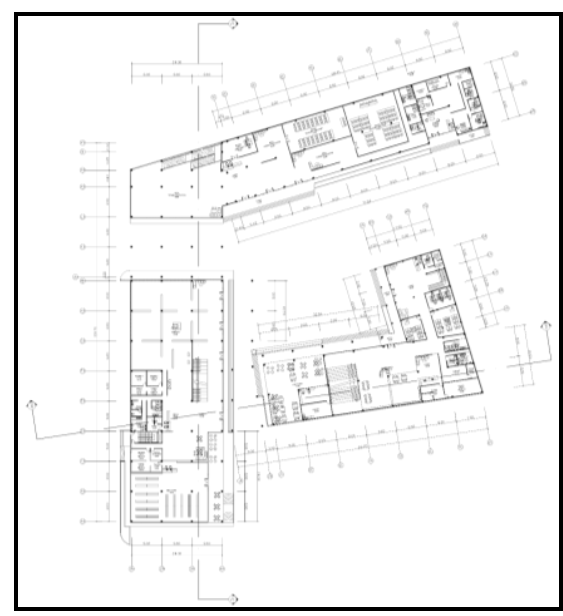

Gambar 14. Denah Lantai Dasar

Sumber: Penulis, 2020 
Denah lantai 1 pada dasarnya merupakan penerusan zonasi atau fungsi dari denah lantai dasar. Adapun fungsi dan kelompok ruang yang baru di sini adalah ruang teater serta ruang baca dan koleksi umum (merupakan penerusan ruang dari lobby utama). Sedangkan untuk ruang-ruang seperti kelompok ruang baca dan koleksi anak serta ruang kelas merupakan penerusan zonasi dari ruangruang yang sebelumnya juga terdapat pada lantai dasar. Untuk denah lantai 1 bangunan dapat dilihat pada Gambar 15 berikut ini.

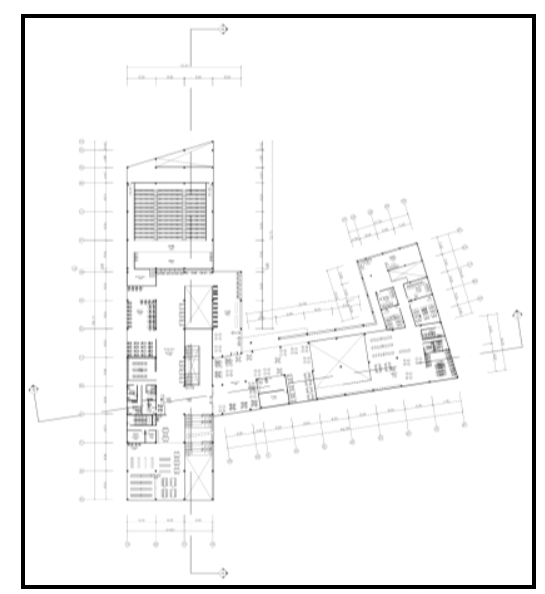

Gambar 15. Denah Lantai 1

Sumber: Penulis, 2020

Tingkatan terakhir yaitu lantai 2 bangunan, hanya akan terdapat kelompok ruang baca dan koleksi umum, yang merupakan terusan dari ruang baca dan koleksi umum yang ada di lantai 1 sebelumnya, serta terdapat pula kelompok ruang servis beserta tangga darurat yang memang di teruskan secara vertikal dari lantai dasar. Untuk koneksi antara lantai 1 dan 2 ini akan dikoneksikan dengan tangga selebar 8 meter, yang fungsinya tidak hanya sekedar sebagai jalur transportasi namun dapat juga difungsikan sebagai area baca, duduk, serta diskusi. Adapun denah lantai 2 dapat dilihat pada gambar 16 berikut ini.

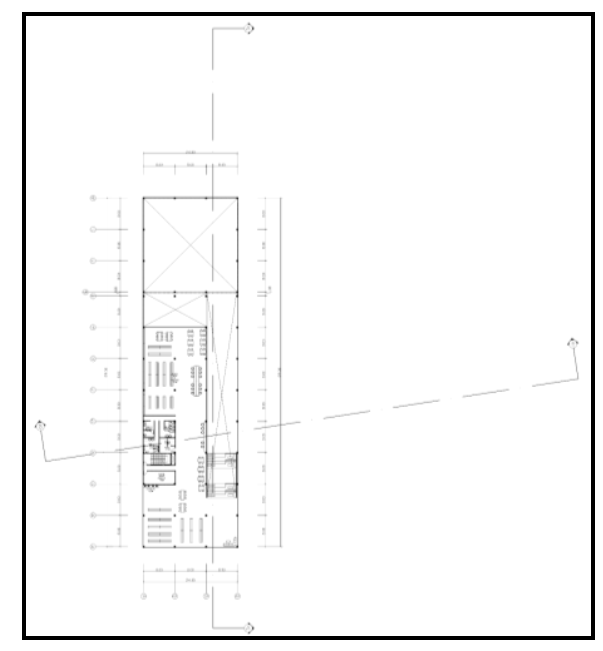

Gambar 16: Denah Lantai 2

Sumber: Penulis, 2020 


\section{Tampak}

Tampak pada bangunan Pusat Literasi Kota Pontianak ini akan didominasi oleh corak berupa huruf-huruf yang di susun secara acak pada setiap sisi bangunannya. Corak-corak huruf ini pada dasarnya memiliki peran sebagi penegasan dari fungsi bangunan yang pada umumnya identik dengan elemen huruf di dalamnya. Selain berperan sebagi pembentuk wajah dan citra bangunan, corak huruf-huruf ini juga pada dasarnya merupakan secondary skin yang berperan sebagai penghalau silau matahari serta menghalau sinar matahari yang membawa panas untuk menyikapi temperatur serta iklim panas pada lokasi perancangan.

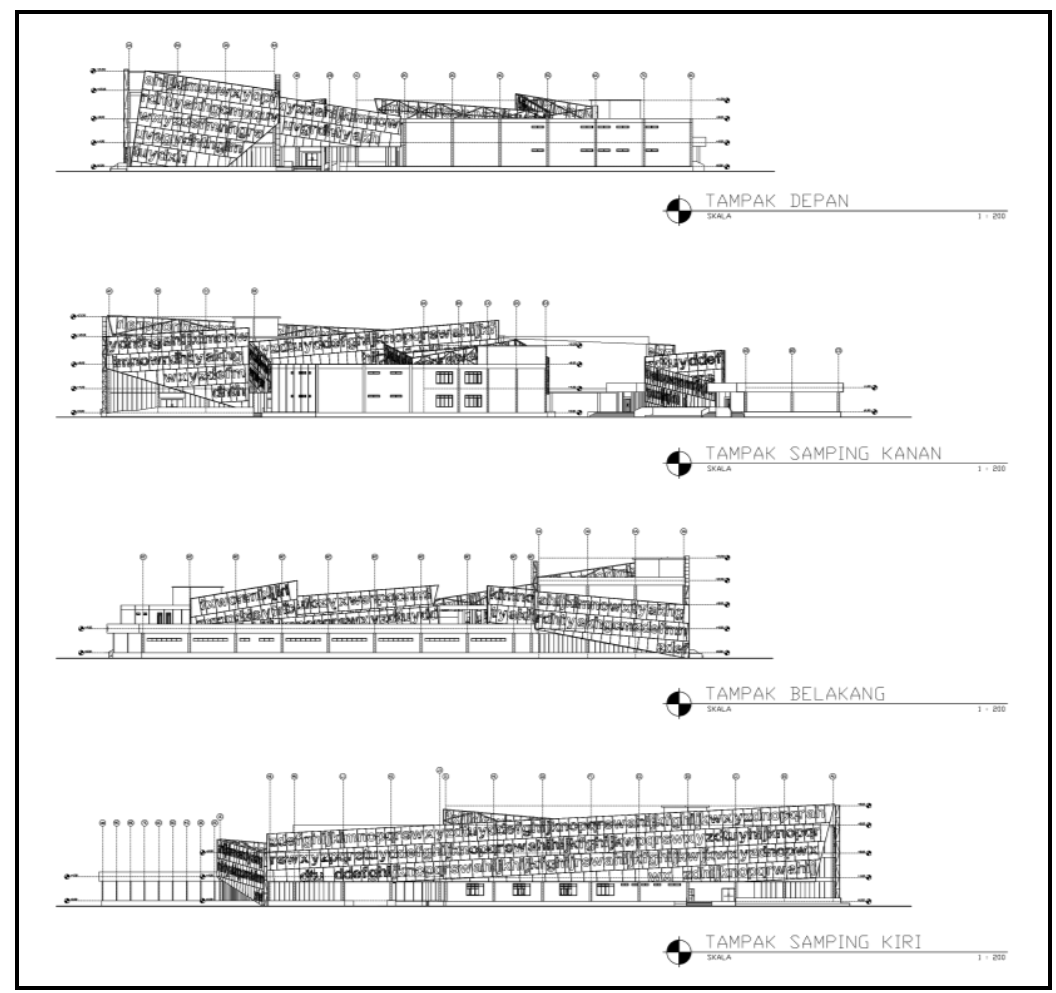

Gambar 17: Tampak Bangunan

Sumber: Penulis, 2020

\section{Potongan}

Potongan bangunan Pusat Literasi Kota Pontianak menunjukkan beberapa hal dari gambaran keseluruhan perancangan. Salah satu yang paling mencolok adalah berkenaan dengan struktur dan konstruksi yang akan digunakan di dalam perancangan. Sesuai dengan analisis yang telah di lakukan pada bagian sebelumnya, struktur dan konstruksi yang akan di gunakan dan tertera di dalam potongan bangunan Pusat Literasi ini adalah struktur dan konstruksi beton bertulang, mulai dari balok, kolom hingga plat lantai. Selain daripada itu untuk konstruksi atap bangunan tentunya akan terbagi menjadi 2 klasifikasi yaitu atap beton bertulang serta atap miring (bentang lebar pada ruang teater dan konstruksi atap miring baja ringan). Adapun salah satu detail potongan Pusat Literasi Kota Pontianak dapat dilihat pada Gambar 18 berikut ini. 


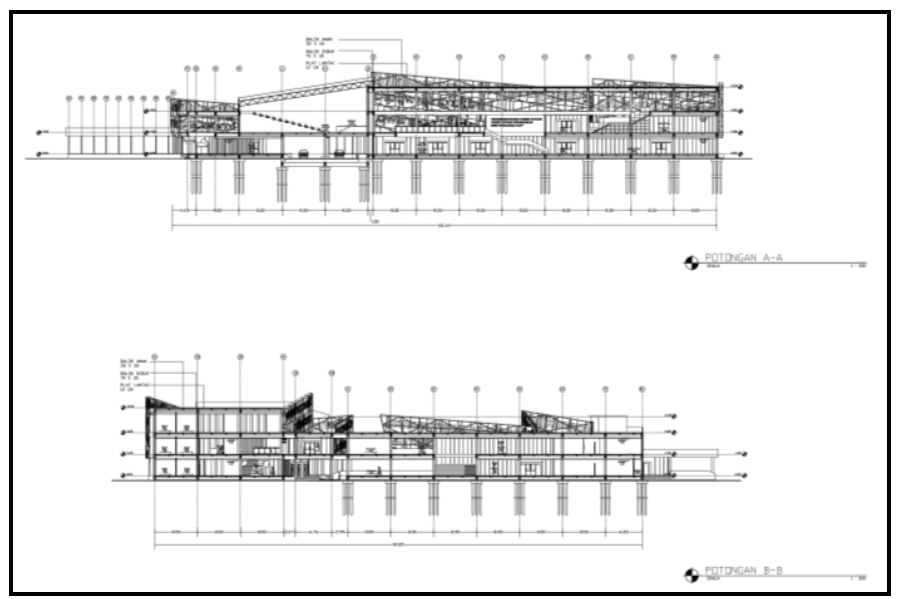

Gambar 18. Potongan Bangunan

Sumber: Penulis, 2020

\section{Suasana Ruang Luar dan Ruang Dalam}

Suasana eksterior bangunan pada dasarnya akan di dominasi oleh penampakan corak-corak acak yang menyelubungi setiap sisi masa bangunan. Suasana tersebut tentunya akan meningkatkan kesan bangunan sebagai pusat literasi di mana seluruh aktivitasnya akan berpacu dengan huruf-huruf baik lisan maupun tulisan. Selain daripada suasana huruf-huruf dari fasade bangunan, suasana eksterior juga akan di dominasi oleh aktivitas-aktivitas outdoor yang memang di sediakan untuk pengunjung maupun komunitas. Terutama pada taman di tengah bangunan, yang memang di peruntukan dan ditata sedemikian rupa untuk area diskusi terbuka, sehingga pengunjung bebas untuk memanfaatkan area tersebut untuk melakukan kegiatan-kegiatan berbasis literasi. Untuk lebih jelas mengenai suasana eksterior bangunan dapat dilihat pada Gambar 19 berikut ini.

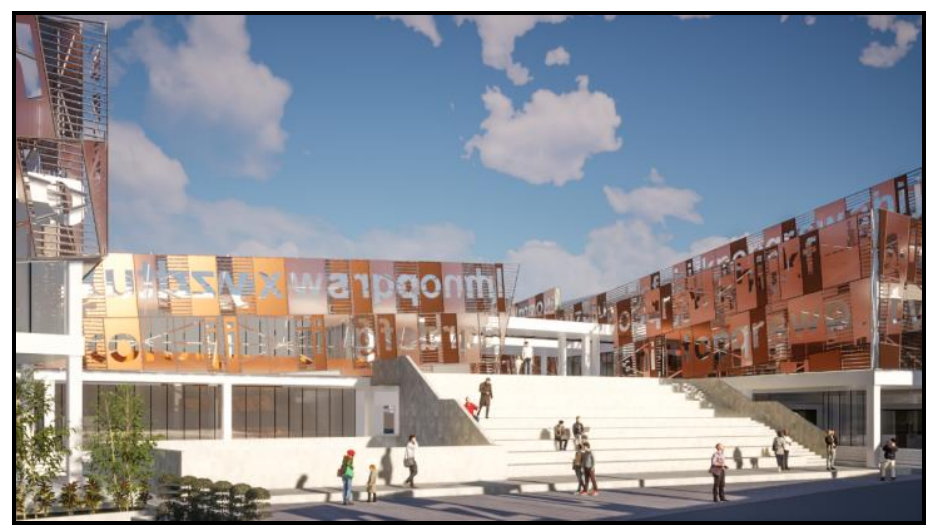

Gambar 19. Suasana Ruang Luar

Sumber: Penulis, 2020

Suasana interior di dalam ruang-ruang Pusat Literasi Kota Pontianak pada dasarnya akan memiliki nuansa yang saling berbeda. Perbedaan nusa setiap ruangan tersebut pada dasarnya akan menyesuaikan dengan fungsi-fungsi daripada ruang-ruang tersebut, seperti hanya ruang baca dan koleksi anak akan memiliki dekorasi interior yang akan berbeda dengan dekorasi interior ruang baca dan koleksi umum. Namun secara garis besar terdapat sebuah konsep yang akan menyatukan seluruh ruangan dan fungsi di dalam bangunan Pusat Literasi Kota Pontianak ini yaitu suasana interior juga akan di dominasi oleh tulisan-tulisan, baik pada dinding, lantai, maupun plafon ruangan. Bukan berupa huruf-huruf acak seperti yang ada pada eksterior, melainkan kutipan-kutipan quotes dari 
tokoh-tokoh terkenal serta kata-kata motivasi dan lain-lain. Untuk lebih jelas mengenai suasana eksterior bangunan dapat dilihat pada Gambar 20 berikut ini.

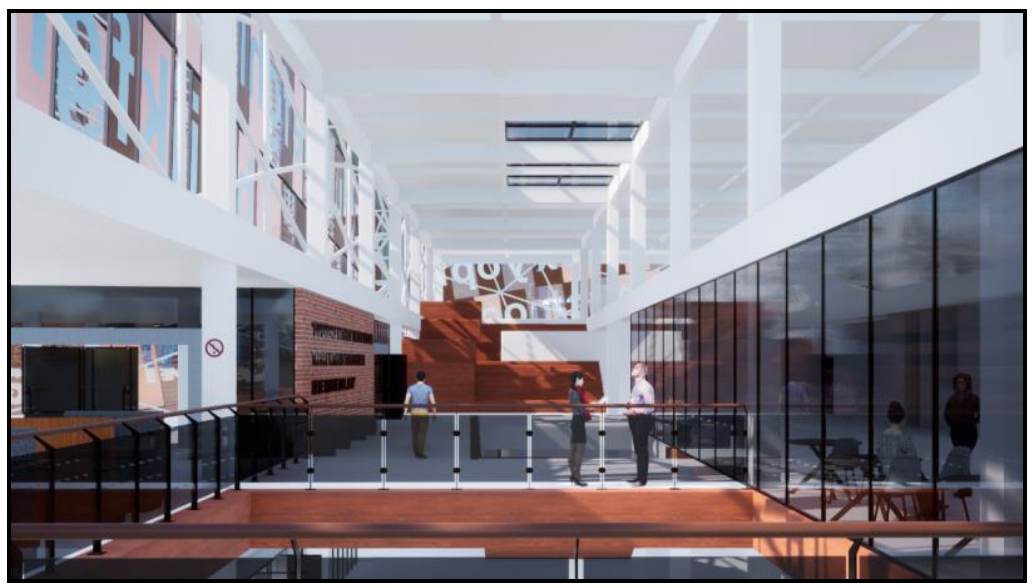

Gambar 20. Suasana Ruang Dalam

Sumber: Penulis, 2020

\section{Kesimpulan}

Kesimpulan yang dapat ditarik dari perancangan Pusat Literasi Kota Pontianak ini adalah bagaimana metode design thinking dapat memberikan sebuah solusi ruang dari segi arsitektur yang dinilai dapat membantu menaikan taraf literasi di Kota Pontianak. Melalui fasilitas kompleks yang ada di dalam bangunan ini serta berbagai analisis yang di lakukan terhadap aktivitas, kegiatan dan komunitas literasi, tentunya menjadikan Pusat Literasi Kota Pontianak yang pada dasarnya merupakan suatu terobosan baru, akan sekaligus menjadi icon literasi yang dapat membangun kembali buaya literasi yang telah lama merosot di Kota Pontianak. Selain daripada itu dari segi pengalaman ruang, konsep eksterior, serta lokasi yang strategis, tentunya juga akan berperan dalam menarik minat banyak kalangan di Kota Pontianak yang sebelumnya tidak memiliki akses atau belum masuk ke dalam dunia literasi yang lebih konkret.

\section{Ucapan Terima Kasih}

Ucapan terima kasih kepada Bapak Affrylyno, S.T., M.Sc., selaku Dosen Penguji Utama; Bapak Tri Wibowo Caesariadi, S.T., M.T., selaku Dosen Penguji Pendamping sekaligus dosen PA; serta kepada seluruh Dosen dan Staf Program Studi Arsitektur Universitas Tanjungpura yang telah memberikan ilmu yang bermanfaat selama ini.

\section{Daftar Pustaka}

Assessment, C. (2013). What is Literacy? An Investigation into Definition of English as a subject and the relationship between English, Literacy and "being literate". London: UCLES.

Brown, T. (2009). Change by Design: How design thinking transforms organizations and inspires innovation. New York: Harper Business.

Clay, M. (2001). Change over time in children's literacy development. Porthsmouth: Heinemann dalam Direktorat Jenderal Pendidikan Dasar dan Menengah. (2016). Desain Induk Gerakan Literasi Sekolah. Jakarta: Kementrian Pendidikan dan Kebudayaan.

De Yong, S. (2017). Silabus Desain Interior \& Styling 2. Surabaya: Universitas Kristen Petra.

Kambel, G. (2009, 08 14). Awekening Creativity. Diambil dari Chauntauqua Lecture.

Kebudayaan, K. P. (2019). Indeks Aktivitas Literasi Membaca 34 Provinsi. Jakarta: Pusat Penelitian Kebijakan Pendidikan dan Kebudayaan, Badan Penelitian dan Pengembangan, Kementerian Pendidikan dan Kebudayaan .

Kren, R. (2000). Literacy \& Language Teaching. Oxford: Oxford University.

Nasution. (2013). Berbagai Pendekatan dalam Proses Mengajar. Jakarta: Bumi Aksara. 